\title{
The morphotectonic structure of the lower Jordan Valley - an active segment of the Dead Sea Rift
}

\author{
S. Belitzky \\ Department of Geophysics and Planetary Sciences, Tel Aviv University, Israel (Email: sbel@ bezeqint.net)
}

Received: 7 November 2000 - Revised: 16 January 2002 - Accepted: 29 January 2002

\begin{abstract}
The pioneering morphotectonic study of young structures and movements in the central segment of the Dead Sea Rift, along the lower Jordan Valley, included analysis of the relief, drainage network, and remote sensing images. The Dead Sea Rift is the major transform along which the Arabian plate has moved sinistrally with respect to the African plate about $100 \mathrm{~km}$ from the Neogene to the Recent. The lower Jordan Valley surface is covered by the late Pleistocene Lisan lacustrine Formation and by the Holocene clastic deposits. The transform in the lower Jordan Valley is composed of three major segments: northern Kinnarot, southern Jericho, and the connecting them Malih. The Kinnarot and the Jericho segments were formed under transtension and both trend N-S; in them elongated pull-apart basins have developed. In these basins clastics and evaporites were accumulating since the Late Miocene. The NNE-trending Malih segment was formed under transpression that formed the Malih uplift. Uplifted and subsided areas identified along the lower Jordan Valley indicate vertical rather than lateral motions: almost no evidence of lateral displacement was found there. Dominance of vertical motions suggests that the neotectonic regime was governed by continuous N-S extension of the Israel-Sinai plate and by transverse movements during the Arabian plate "escape". Locations of earthquakes are concentrated in the Shomeron Triangle. This can be explained by rejuvenation of the Triangle faults induced by ongoing $\mathrm{N}$ $\mathrm{S}$ extension of the Sinai sub-plate. N-S extension on the west results in decrease of the rate of the lateral motion along the transform in the lower Jordan Valley.
\end{abstract}

\section{Introduction}

This work is based on the results of the morphotectonic study (Belitzky, 1996) of the young structures and motions in the central segment of the Dead Sea Rift that stretches from the Dead Sea to the Kinneret Lake (Fig. 1) along the lower Jordan Valley. The study included analysis of relief, drainage network, pattern of sediment removal and accumulation, and remote sensing images. Relatively poor exposure of the geological formations and paucity of geophysical information prompted emphasis on tectonic geomorphology of the region. Whenever it was possible, the results of the morphotectonic analysis were integrated with geological, geophysical, hydrological and archeological data.

The Dead Sea Rift is the $1000 \mathrm{~km}$ long major transform that links the Red Sea spreading area with the Zagros-Taurus zone of plate convergence along which the Arabian plate has moved sinistrally with respect to the African plate (Fig. 1). The accumulated horizontal displacement is about $100 \mathrm{~km}$ dating from Neogene to Recent (Garfunkel et al., 1981). Because of this, kinematic analysis of the Dead Sea Rift has focused on horizontal rather than vertical displacements. Where it is obvious, young vertical deformation was attributed to local variations in patterns of the transform faults and generation of local stress fields due to lateral displacements such as pull-aparts and push-ups. The kinematic model (Joffe and Garfunkel, 1987) suggests that neotectonic deformation in the lower Jordan Valley is influenced by regional as well as by local strain fields. The regional deformation is induced by NE tension and NW compression. The original, parallel to the transform, direction of the Arabian plate motion changed slightly about $5 \mathrm{MY}$ ago and includes counter-clockwise rotation relatively to the Israel-Sinai plate. As a result of the change, diagonal compression was induced in the Lebanon segment of the transform, while transverse tension component (transtension) was induced along the southern segment, from the Red Sea to the Northern Jordan Valley. This tensional component produced transverse extension of several kilometers and the morphotectonic valley configuration.

While the kinematic model of Joffe and Garfunkel (1987) provides a general conceptual framework for interpretation of the transform development history, many details of the plate boundary and kinematics still are not clear. As a result, there is major discrepancy between observed structural pattern and predicted by geodynamic models. This paper presents the summary of the tectonic geomorphology study 


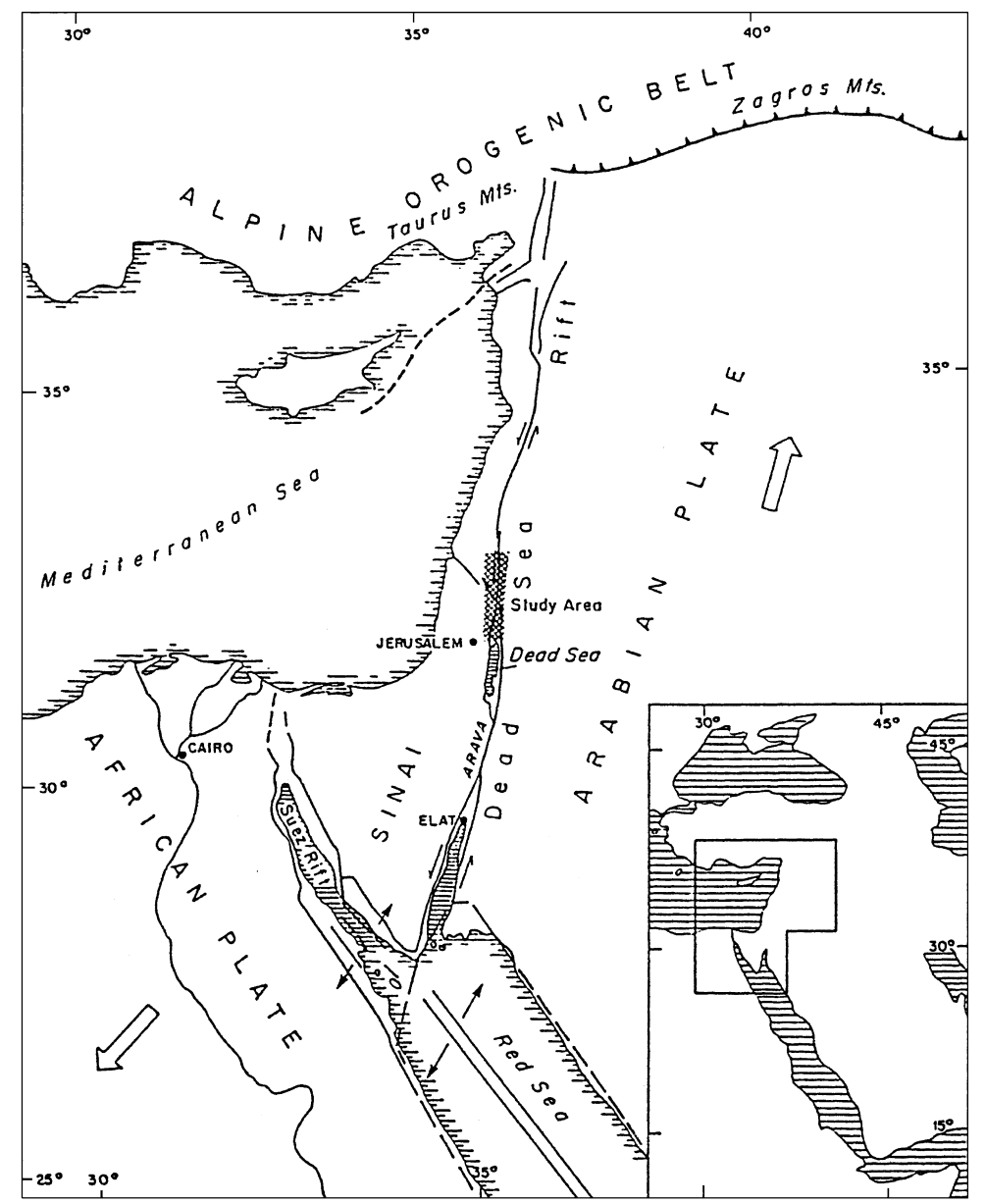

Fig. 1. Location map of the study area.

that was conducted with purpose to find reasons for the discrepancy.

In the Dead Sea Rift, the direction of the plate boundary changes several times, and the areas of transpression and transtension were formed along the transform (Belitzky, 1996). Mechanical properties of the plates are different (Reches, 1987), and there are numerous structures that originated in the pre-transform period. Some of these structures are active and exhibit recent seismic activity (Salamon et al., 1996). Seismic efficiency of the Dead Sea transform is very low (about 7\%); moderate seismic activity that spread out in wide belts reflects the complexity of deformation along the plate border (Salamon et al., 1996).

The lower Jordan Valley segment bounds on the east the northern portion of the Sinai sub-plate (Salamon et al., 1996). This portion of the Sinai sub-plate, to the north of the Dead Sea, was formed in one of the most complicated areas of the Dead Sea Rift, in the area of coherent plates breakup, in front of the plate collision zone to the north (Ben-Avraham et al., 1996).

This situation produces structural complexity that is compounded even more by superposition of the Rift shoulder deformation processes (Belitzky, 1996; Matmon et al., 1999).
Indeed, paleomagnetic studies (Ron et al., 1984; Baer and Mimran, 1993; Achmon, 1997) showed extremely complex pattern of deformation of the Sinai sub-plate to the north of the Dead Sea. Non-rotating domains, bounding rotating ones, suggest the presence of strike-slip between them. Morphotectonic studies (Belitzky, 1996) and seismic activity (Salamon et al., 1996) show that contemporaneous deformation occur mostly to the west of the Dead Sea transform. There are only few lateral movements and that fact is contrary to what it should be expected.

The lower Jordan Valley is the morphotectonic depression that is bordered on the east and the west by faults and flexures. The lower Jordan Valley stretches about $105 \mathrm{~km}$. The valley floor (Ghor, Fig. 2) slopes gradually from $210 \mathrm{~m}$ below MSL (mean level of the Kinneret Lake) to about $414 \mathrm{~m}$ below MSL (the current level of the Dead Sea). The width of the lower Jordan Valley varies from $10 \mathrm{~km}$ on the north to $4-5 \mathrm{~km}$ in Wadi Malih area to $25 \mathrm{~km}$ in the area of the northern shore of the Dead Sea. The morphotectonic depression of the lower Jordan Valley was filled with continental and marine sediments. Zemah-1 well that was drilled in the northern portion of the Valley penetrated more than four kilometers of the rift fill: evaporites, igneous and clastic rocks (Marcus 


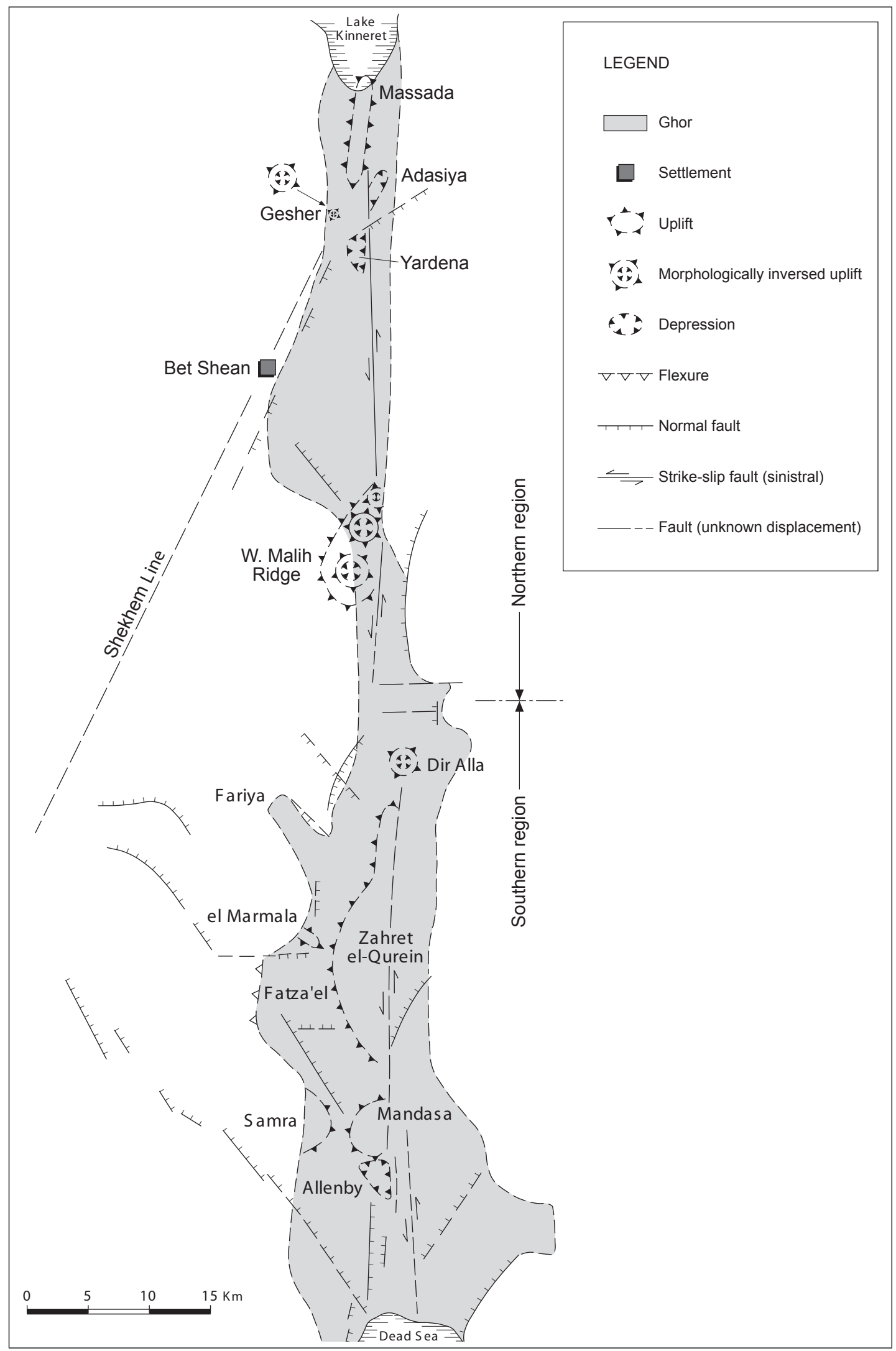

Fig. 2. Map of morphostructures of the lower Jordan Valley. 
and Slager, 1985). In the Latest Quaternary, the rift was covered by the brakish to hypersaline Lisan Lake. At the end of the Pleistocene the Lisan Lake shrunk and retreated from the northern part of the lower Jordan Valley to the Dead Sea area (Horowitz, 1978; Weinstein-Evron, 1993). Several meters of red silty sediments (Fatza'el Mbr.; Horowitz, 1979) were deposited in fresh water bodies in morphological lows that were formed after the retreat of the Lisan Lake. The age of the sediments of the Fatza'el Mbr. is about 8000 to 10000 BP (Schuldenrein and Goldberg, 1981). These clastic sediments were locally covered by colluvium, alluvium, and dust-loess soils (Lili Mbr.; Belitzky, 1996).

Elements of the lower Jordan Valley structure and deformation are concealed and obscured by this cover. Young faulting and folding movements cause deposition of the surface material and erosion in sinking and uplifting areas respectively. It is combination of tectonic deformation and surface processes that produced the morphostructures of the lower Jordan Valley. In absence of detailed geophysical surveys, it is the finer details of geomorphological surface pattern that allow identification of ongoing tectonic activity.

\section{Morphostructures of the lower Jordan Valley}

Morphostructural analysis (analysis of morphology and drainage net) detected in the lower Jordan Valley numerous folded and faulted morphotectonic structures (morphostructures) and pattern of neotectonic deformation. Some morphostructures were unknown before in the lower Jordan Valley, and young tectonic deformations of the structural elements were considered inactive. For example, many of the lower Jordan Valley boundary faults were considered inactive in the post Lisan Lake times (Garfunkel et al., 1981). Morphological analysis revealed that there are recent motions in the area. One of the most interesting phenomena detected in the lower Jordan Valley is the formation of the morphological inversion on the apex of uplifted structures. This morphological inversion appears in the areas of pressure (W. Malih Ridge, Fig. 2) as well as in the areas of tension (Deir Alla and Gesher, Fig. 2). In the areas of pressure morphological inversion was formed by augmented erosion of uplifted structures, and in the areas of tension by dissolution and collapse of evaporites in the uplifted diapir structures (Belitzky, 1996).

Morphostructural analysis reveals also that the faults in the center of the lower Jordan Valley are longitudinal, parallel to the N-S direction of the Valley (Fig. 2). It was assumed that these N-S oriented faults represent the transform. These faults do not manifest systematic lateral displacement of wadis and gullies that were formed mainly in the Holocene in the lower Jordan Valley. Directions of the faults on the east and the west are ranging from diagonal to normal to the Valley. The faults of the transform in the lower Jordan Valley split and bend eastward (Fig. 2), like in the adjacent segments of the rift (Reches, 1987). There are small-scale vertical deformations in the areas of the eastward bending transform faults. On the west, transverse faults do not split off the transform faults and do not bend. Most of these faults are eastward extensions of the faults of the lower Jordan Valley western shoulders.

\section{Major segments of the lower Jordan Valley}

Morphostructural analysis shows that the transform in the lower Jordan Valley is composed of three major segments (Fig. 3a,b): northern Kinnarot, southern Jericho, and the connecting Malih segment. The Kinnarot and the Jericho segments trend N-S. The Malih segment is NNE directed. Morphostructural analysis (Belitzky, 1996) as well as geological and geophysical data (ten Brink et al., 1999) indicate that two elongated basins were formed in the Kinnarot and the Jericho segments of the lower Jordan Valley. It is assumed that simultaneous formation of these basins is the result of pull-aparts development caused by the Arabian plate left-lateral slip along the faults, whose direction deviates slightly eastward from the valley direction. It is assumed that similar mechanism formed the Dead Sea basin (Zak and Freund, 1981). Clastic sediments and evaporites were accumulating in these basins since the late Miocene.

Motion of the Arabian plate that includes a component normal to the valley results in accumulation of sediments of considerable thickness in the Jericho and the Kinnarot basins. These sediments pushed up evaporites like in the diapirs of the southern Dead Sea basin (Zak and Freund, 1981). The process resulted in the formation of tier of uplifted morphostructures: Massada and Gesher in the Kinnarot basin, and Zaharet el-Qurein, Dir Alla and Mandasa in the Jericho basin (Fig. 2).

The Malih segment is bounded by steep flexures. The area reveals local pressure and folding in the Neogene and the Early Pleistocene caused by "friction" between the plates (Garfunkel, 1981). The area comprises morphological and structural "bottleneck" in the lower Jordan Valley, because the valley width there is only about $4 \mathrm{~km}$. In this area the old valley fill is uplifted and exposed, and in turn it is covered unconformably by the Lisan Lake sediments (Schulman and Rosental, 1968). As it appears on geological profiles (Begin et al., 1974), the Lisan sediments in the Malih area were uplifted.

Longitudinal profiles of the lower Jordan Valley surface and of the Jordan River terraces at the Malih segment are anomalously convex that indicates recent uplift of about 15$20 \mathrm{~m}$ (Belitzky, 1996). The Jordan River and its affluents have V-profiles at their cross-sections that is characteristic for vertical incision in response to the local uplift.

The NNE direction of the Malih segment conforms to the left lateral synthetic slip in the area of transpression (Fig. 3b). To the west of the transform, the Malih area of pressure and uplift developed the Malih ridge. The ridge forms NNE trending positive gravity anomaly (Bender, 1968) and consists of morphologically inversed morphostructures on the west of the transform (Fig. 2). As suggested by Wiesemann 


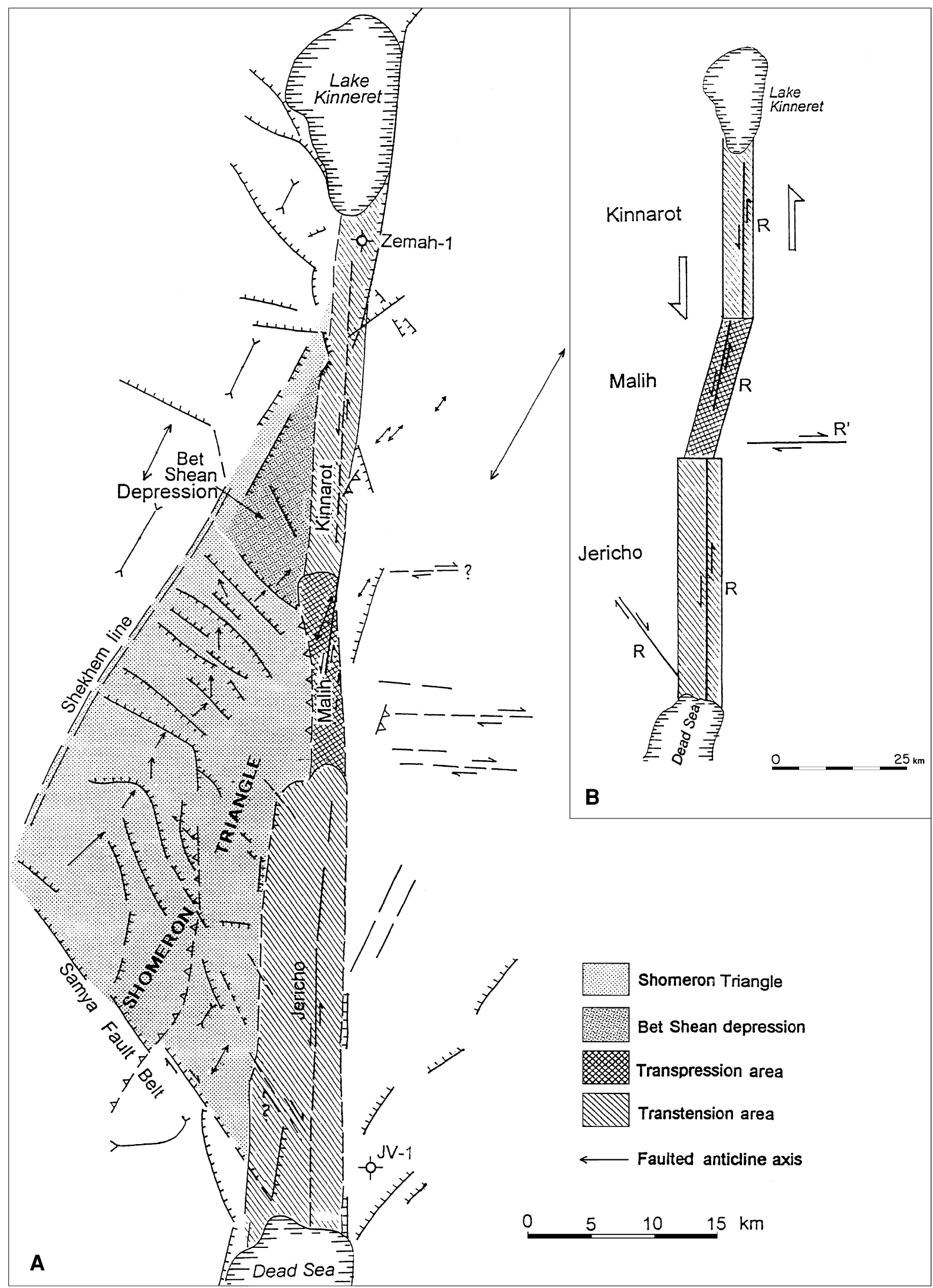

Fig. 3. (a) Map of major structural elements at the lower Jordan Valley and of the Shomeron Triangle structure. The map shows basins of the Jericho and the Kinnarot, divided by uplifted area of Malih. (b) Schematic map of transpression and transtension zones and direction of main lateral faulting at the low Jordan Valley (R-synthetic; R'-anthytetic dextral faults). 
(1969), E-W trending faults with right-lateral component of displacement have developed on the east. Right-lateral slip on the EW faults should produce counter-clockwise rotation of the transform faults in the Malih segment.

\section{The Shomeron Triangle}

The western part of the lower Jordan Valley and adjacent area are affected by the development of the Shomeron Triangle structure (Fig. 3a). Locations of small earthquakes are concentrated in the Shomeron Triangle (Fig. 4). The structure is delimited on the west by tectonic lines of NW and NE directions and on the east by the transform faults. On the south, the Shomeron Triangle is bounded by a structural line composed of the Samia faults belt (Begin, 1975) and its NW and NE extensions. Faults of this structural line are normal with right-lateral component (Begin, 1975). Right-lateral movement on NW trending faults conforms to antithetic shear to be expected in the area of transtension (Fig. 3b). The structural line bounds on the south the area of the Shomeron and the Galilee NW trending normal faults. On the west, the Shekhem line (Fig. 3a) bounds the Shomeron Triangle.

\section{The Shekhem line}

The Shekhem line extends from the Shekhem area (Sahel Mahne) on the south to the area of the Dead Sea Rift (the Kinnarot Valley) to the north of the Bet Shean Valley (Fig. 3a). The Shekhem line forms the eastern boundary of uplifted and tilted to the west area. Searching for the southern extension of the line led to discovery that it is the northeastern extension of the Sadot fault line that runs through the Judea mountains to the west of the Ramallah toward the Sinai (Bartov and Rotstein, 1989). The Sadot line is the ancient fault line that dates back to the Lower Jurassic. The line divides structurally uplifted area on the west and an area with thickened crust on the east. The Sadot line was active during periods following the Jurassic including the Neogene. There are manifestations of intensive faulting and folding along the line including the overturned Cretaceous strata. It was suggested that the Sadot line is the southwestern extension of the Hermon-Palmira line that was moved to the north together with the Arabian plate (Bartov and Rotstein, 1989). Normal to the Shekhem line seismic profile revealed a flower structure that suggests sinistral displacement (Brown and Flexer, 1991).

\section{Discussion}

\subsection{Major segments and structures}

The transform in the lower Jordan Valley is composed of three major segments (Fig. 3). The northern and the southern segments, Jericho and Kinnarot, were formed under transtension; they have a N-S direction. It is assumed that simultane- ous formation of elongated basins along these segments was the result of the development of pull-aparts caused by the Arabian plate left-lateral slip along the faults, whose direction deviates slightly eastward from the Valley direction. In these basins clastics and evaporites were accumulating since the late Miocene until the Recent. Continuous motion of the Arabian plate accompanied by subsidence and sediment accumulation in the basins resulted in the uplift of diapirs of evaporites.

The NNE-directed Malih segment was formed under transpression that is the result of lateral slip combined with friction and pressure of the plates in the Malih area. The transpression caused formation of the Malih ridge to the west of the transform and, apparently, produced counterclockwise rotation of the transform faults in the Malih segment. The rotation was accompanied by right-lateral slip on the E-W faults to the east of the transform. Counterclockwise rotation of the transform faults brought direction of the Malih segment closer to the direction of Arabian plate motion, diminishing transpression component in the Malih segment.

On the west, structural evolution was influenced by formation of the Shomeron Triangle faulted blocks structure (Fig. 3a). The structure constitutes southern expansion of the Galilee NW faulting. The triangle NW faults are mostly normal with a dextral component (Begin, 1975) that, apparently, was induced by rotations of the Triangle blocks. The rotation resulted in the N-S extension and brought about EW compression, and, probably, origination of the Bet Shean depression (Baer and Mimiman, 1993).

Continuing processes of N-S extension of the Sinai subplate brought about rejuvenation of NW trending normal faults of the Shomeron Triangle in Jericho and Kinnarot areas and of the similar NE trending faults in several locations on the west. Rejuvenation of NW and NE normal fault systems led to the formation of triangular depressions, like Bet Shean Valley in its present configuration.

\subsection{Vertical vs. lateral motions}

Vertical rather than lateral motions created uplifted and subsided areas identified along the lower Jordan Valley. Almost no direct evidence of a lateral displacement was found. The dominance of vertical motions suggests that the neotectonic regime is governed by continuous N-S extension of the Israel-Sinai plate and by transverse movements during the "escape" of the Arabian plate.

Analysis of morphological features (Belitzky, 1996) and of seismisity (Salamon et al., 1996) in the lower Jordan Valley area indicates that only a small fraction of recent tectonic activities to the north of the Dead Sea is the direct result of lateral movements. In addition to the simple plate translation, there are also processes of deformation in the area that are induced mostly by N-S extension on the west and EW transverse extension. They create a "weak" area in the lower Jordan Valley.

Small earthquakes suggest continuing blocks' movement (Mogi at al., 1991). In the area under the study, locations 


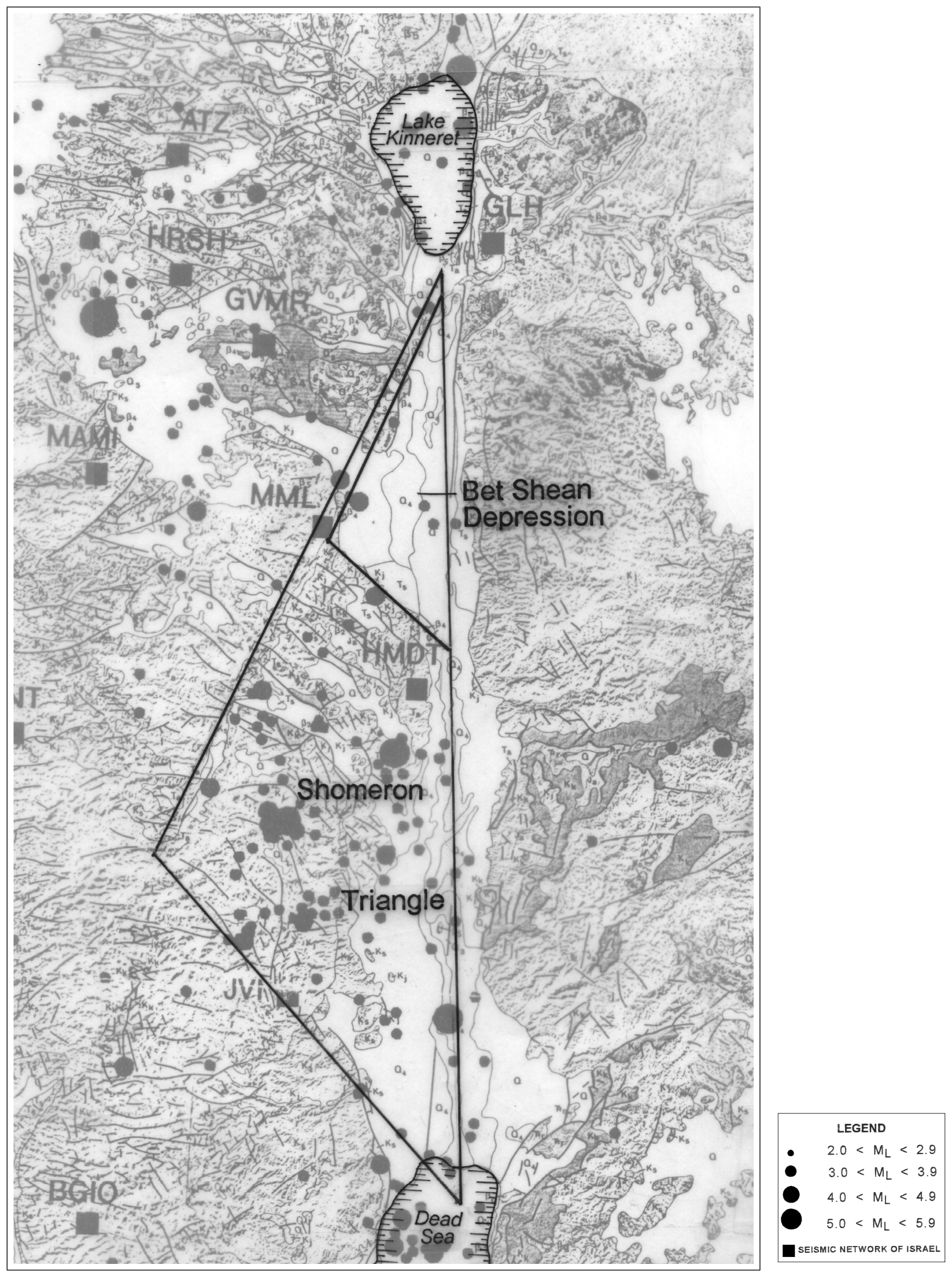

Fig. 4. Locations of earthquakes at the lower Jordan Valley (based on the map of earthquakes by Bartov (1994). The map shows concentration of the earthquakes locations in the Shomeron Triangle. 
of such earthquakes are concentrated in the Shomeron Triangle. This can be explained by rejuvenation of the Triangle faults induced by ongoing N-S extension of the Sinai subplate. The N-S extension along the lower Jordan Valley segment represents a part of the similar process in the adjacent area of the Galilee (Ron et al., 1984).

$\mathrm{N}-\mathrm{S}$ extension on the west results in decrease of the rate of lateral motion along the lower Jordan Valley, so the vertical component of a movement becomes more prominent. This phenomena allows to explain the paradoxical situation, when modern geomorphic and seismic data indicate numerous vertical movements, mostly in the west, and only few lateral movements, whence there are the lateral movements that should be the result of plain plates translation. The apparent explanation of the fact is that the decrease of lateral displacement between the plates develops. At least, a part of accommodation of lateral motions on the west by vertical deformations is manifested in large part by elongation of the Sinai sub-plate. Similar process of accommodation of lateral motions by vertical deformations was described in the Galilee (Ron et al., 1984), in the Northern Anatolia (Barka, 1992), and in the Basin and Range Province in the SanAndreas transform area (Sylvester, 1988). There are also the small-scale vertical deformations along the eastern part of the lower Jordan Valley in the areas of eastward bending faults of the transform. Similar pattern of deformation was described along the eastern shoulder of the northern Jordan Valley (Reches, 1987).

\section{Synthesis and Conclusions - the structure of the lower Jordan Valley segment and the formation of the Dead Sea Rift}

Recently compiled Bouger gravity anomaly map (ten Brink et al., 1999) shows numerous basins of various sizes and shapes occupying the Rift Valley and the plate boundary comprising numerous and relatively short fault segments. This phenomenon underscores the fact that the origin of the Dead Sea rift (Lyakhovsky et al., 1994) as well as its further development is still unclear. Indeed, geological and geophysical evidence indicate that two kinds of geodynamic processes occur here simultaneously - the transform motion and a propagation of actual crustal spreading (Ben-Avraham, 1987). Simultaneous formation of elongated pull-aparts in the lower Jordan Valley caused by the Arabian plate leftlateral slip along the faults, whose direction deviates slightly eastward from the Valley direction, is a plausible explanation for simultaneous occurrence of transform motion and a propagation of actual crustal spreading.

There are numerous structures that initiated in the pretransform period. Some of these structures are active and exhibit recent seismic activity (Salamon et al., 1996). Because of this, lateral motion produces complex process of folding and faulting, when old structural elements become rejuvenated beside younger. The Shekhem Line (Belitzky, 1996) is the example of a rejuvenated old structure. It is the segment of the ancient fault line that most probably dates back to the Lower Jurassic. Its rejuvenation produces a major discrepancy between the observed neotectonic pattern and current seismotectonic activity and predicted by geodynamic models in the lower Jordan Valley segment of the Dead Sea transform. The geomorphic and seismic data indicate numerous vertical movements, mostly on the west, and only few lateral movements. This is contrary to what should be expected according to the models.

This example of structural development of the lower Jordan Valley segment demonstrates how integration of older structures actually affects modern structural pattern of a plate boundary and its deformation processes. It is the additional reason, why the observed situation is substantially different from the predicted by existing models. Hence, the structure and young tectonic motions in the Dead Sea Rift should be studied in the broader context of the neotectonic structure and deformations in the surrounding and adjacent areas.

Acknowledgements. This study would not be possible without energetic leadership, support, and special efforts rendered at all its stages by Professor I. Zak, Professor Y. Kartcz and Dr. S. Goltz. Special thanks to Dr. G. Shaliv and Dr. E. Zilberman. P. Grossman prepared illustrations for the paper. The study was supported by grant of Regional Research and Development Center - Samaria and Jordan Rift.

\section{References}

Achmon, M.: Paleomagnetic and geophysical research of the Carmel Fault Zone, PhD, Tel-Aviv University, 1997.

Baer, G. and Mimian, Y.: Paleomagnetism and Structural History of the Fari'a anticline, eastern Shomeron, Geological Society of Israel Current Recearch, 8, 58-61, 1993.

Barka, A. A.: The North Anatolian fault zone, Annales Tectonicae 6, 164-195, 1992.

Bartov, Y. and Rotstein, Y.: Sadot fault - a significant geological and geophysical boundary in the Middle East, Israel Geological Society annual meeting, Ramot, 15 pp, 1989.

Begin, B. Z., Ehrlich, A., and Nathan, Y.: Lake Lisan, the Pleistocene precursor of the Dead Sea, Israel Geological Survey Bulletin, 63, 1-30, 1974.

Begin, B. Z.: The geology of the Jericho area. Bulletin of Geological Survey of Israel 67, 1-35, 1975.

Belitzky, S.: Tectonic geomorphology of the lower Jordan Valley - an active continental rift, $\mathrm{PhD}$, Hebrew University, Jerusalem, 1996.

Ben-Avraham, Z.: Rift propagation along the southern Dead Sea rift (Gulf of Eilat), Tectonophysics, 143, 193-200, 1987.

Ben-Avraham, Z., ten Brink, U., Bell, R., and Reznikov, M.: Gravity field over the Sea of Galilee: Evidence for a composite basin along a transform fault, Journal of Geophysical Research, 101, 533-544, 1996.

Bender, F.: Geologie von Jordanien. Beiträge zur regionalen Geologie der Erde, vol. 7., Berlin, Gebr. Bornträger, 1968.

Brown, M. and Flexer, A.: Tectonics and volcanism at the Gilboa shoulders, Israel Geological Society annual meeting-field trips guide, Akko, 104-115, 1991. 
Garfunkel, Z.: Internal structure of the Dead Sea leaky transform (rift) in relation to plate kinematics, Tectonophysics, 80, 80-108, 1981.

Horowitz, A.: The Quaternary evolution of the Jordan Valley, in: Lake Kinneret, Monografiae Biologicae, vol. 32, 33-43, 1978.

Horowitz, A.: The Quarternary of Israel, Academic Press, New York, 1979.

Joffe, S. and Garfunkel, Z.: Plate kinematics of the Circum Red Sea - a re-evaluation, Tectonophysics, 141, 5-22, 1987.

Lyakhovsky, V., Ben-Avraham, Z., and Achmon, M.: The origin of the Dead Sea rift, Tectonophysics, 240, 29-43, 1994.

Marcus, E. and Slager, J.: The sedimentary-magmatic sequences of the Zemah-1 well (Jordan - Dead Sea Rift, Israel) and its emplacement in time and space, Israel Journal of Earth Science, 34, 1-10, 1985.

Matmon, A., Enzel, Y., Zilberman, E., and Heimann, A.: Late Pliocene and Pleistocene reversal of drainage systems in northern Israel: tectonic implications, Geomorphology, 28, 43-59, 1999.

Mogi, T., Katsura, I., and Nishimura, S.: Magnetotelluric survey of an active fault system in the northern part of Kinki District, southwest Japan, Journal of structural geology, 13, 235-240, 1991.

Reches, Z.: Mechanical aspects of pull-apart basins and push-up swells with application to the Dead Sea Transform, Tectonophysics, 141, 75-88, 1987.

Ron, H., Freund, R., Garfunkel, Z., and Nur, A.: Block rotation by strike-slip faulting structural and paleomagnetic evidence, Journal of Geophysical Research, 89, 6256-6270, 1984.

Salamon, A., Hofstetter, A., Garfunkel, Z., and Ron, H.: Seismicity of the eastern Mediterranean region: Perspective from the Sinai subplate, Tectonophysics, 263, 293-305, 1996.

Schuldenrein, J. and Goldberg, P.: Late Quaternary paleonvironments and prehistoric site distributions on the Lower Jordan Valley, Paleorient, 7, 57-71, 1981.

Schulman, N. and Rosental, E.: Neogene and Quaternary of the Marma Feiyad area south of Bet Shean, Israel Journal of Earth Sciences, 17, 54-62, 1968.

Sylvester, A. G.: Strike-slip faults, Geological Society of America Bulletin, 100, 1666-1703, 1988.

ten Brink, U., Rybakov, M., Al-Zoubi, A. S., Hassoune, M., Frieslander, U., Batayneh, A. T., Goldschmidt, V., Daoud, M. N., Rotstein, Y., and Hall, J. K.: Anatomy of the Dead Sea transform, Geology, 27, 887-890, 1999.

Weinstein-Evron, M.: Palaeogecological reconstruction of the Upper Palaeolithic in the Levant, Actes du XIIe Congres International des Sciences Prehistoriques et Protohistoriques, Bratislava, 1993, 259-270, 1993.

Wiesemann, G.: Zur Tectonic des Gebietes östlich des Grabenabschnittes Totes Meer - Jordantal, Beiträge Geologisches Jahrbuch, 81, 215-274, 1969.

Zak, I. and Freund, R.: Asymmetry and basin migration in the Dead Sea Rift, Tectonophysics, 80, 27-38, 1981. 